\title{
Behaviour and mortality of benthic crustaceans in response to experimentally induced hypoxia and anoxia in situ
}

\author{
A. Haselmair ${ }^{1, *}$, M. Stachowitsch ${ }^{1}$, M. Zuschin ${ }^{2}$, B. Riedel $^{1}$ \\ ${ }^{1}$ Department of Marine Biology and ${ }^{2}$ Department of Paleontology, University of Vienna, Althanstrasse 14, \\ 1090 Vienna, Austria
}

\begin{abstract}
Crustaceans are sensitive to hypoxia and are therefore useful indicator organisms for oxygen depletions. We used the experimental anoxia generating unit in the northern Adriatic Sea to artificially induce and document hypoxia and anoxia on a small scale $\left(0.25 \mathrm{~m}^{2}\right.$ per deployment). Behavioural responses and mortalities were documented for 9 crustacean species typical for the sublittoral soft bottom of the Gulf of Trieste. All species showed a similar succession of atypical responses, albeit at different thresholds. The first reaction to declining dissolved oxygen (DO) was avoidance by climbing to more oxygenated (higher) positions. The animals left their shelters, altered their activity patterns, and exposed themselves to a higher risk of predation at mild hypoxia (2 to $1 \mathrm{ml}$ $\left.\mathrm{l}^{-1} \mathrm{DO}\right)$. Moderate hypoxia (1 to $0.5 \mathrm{ml} \mathrm{l}^{-1} \mathrm{DO}$ ) triggered changes in inter- and intraspecific interactions, resulting in aggregations of up to 27 individuals at the highest elevations. At severe hypoxia ( 0.5 to $0.01 \mathrm{ml} \mathrm{l}^{-1} \mathrm{DO}$ ), sublethal responses such as discarding of camouflage (Ethusa mascarone) were recorded, and $54 \%$ of all crustaceans died. Anoxia left most remaining individuals immobile and moribund until death. Almost all responses were related to DO thresholds - hydrogen sulphide $\left(\mathrm{H}_{2} \mathrm{~S}\right)$ had not yet evolved. Pisidia longimana, Galathea spp., and Macropodia spp. were the most sensitive; Pilumnus spinifer and Ebalia tuberosa were the somewhat more tolerant species. Only Nepinnotheres pinnotheres survived prolonged anoxia as well as high $\mathrm{H}_{2} \mathrm{~S}$ concentrations.
\end{abstract}

KEY WORDS: Dissolved oxygen - Hydrogen sulphide • Northern Adriatic Sea • Bioherms · Sublittoral $\cdot$ Eutrophication

Resale or republication not permitted without written consent of the publisher

\section{INTRODUCTION}

Hypoxia and anoxia severely affect coastal benthic ecosystems, resulting in long-term changes in benthic communities and extensive so-called dead zones (Rabalais et al. 2002). Currently, dead zones have been reported in more than 400 systems worldwide (Diaz \& Rosenberg 2008). Diaz (2001) describes water column stratification and eutrophication as the 2 main factors in the development of hypoxia (DO concentrations $<2 \mathrm{ml} \mathrm{l}^{-1}$ ) and anoxia. Approximate equivalencies at $20^{\circ} \mathrm{C}$ and a salinity of 38 are: $1 \mathrm{ml} \mathrm{l}^{-1}=1.43 \mathrm{mg} \mathrm{l}^{-1}=$ $4.18 \mathrm{kPa}=31.35 \mathrm{~mm} \mathrm{Hg}$. These conditions are met in the northern Adriatic Sea, which makes it a case study for intrinsically sensitive shallow coastal marine eco- systems, both with regard to low DO events and to additional anthropogenic impacts (Lotze et al. 2006).

The effects of hypoxia depend on the severity, frequency, and duration of oxygen depletion. During hypoxia, benthic animals show a wide range of atypical responses and behaviours as well as physiological adaptations (Diaz \& Rosenberg 1995, Burnett \& Stickle 2001, Gray et al. 2002, Wu 2002). Prolonged oxygen depletion triggers mass mortalities of the benthic macroepifauna (for the northern Adriatic: Stachowitsch 1984). Altered benthic community structure and composition often mean a loss of ecosystem function and services (Sala \& Knowlton 2006, Levin et al. 2009).

Anoxia in aquatic environments is always associated with elevated levels of $\mathrm{H}_{2} \mathrm{~S}$, a toxicant for aerobic organ- 
isms (Reiffenstein et al. 1992). Anoxia and $\mathrm{H}_{2} \mathrm{~S}$ have synergistic effects on benthic organisms but are difficult to separate, and both should be considered when studying behavioural reactions to anoxia (Vismann 1991).

The present study focuses on crustaceans associated with bioherms or multi-species clumps - the macroepibenthic assemblages typical for the soft bottoms in the Gulf of Trieste, the investigated part of the northern Adriatic Sea. Vagile organisms here account for $7.9 \%$ of total biomass, with crustaceans in third position (Zuschin et al. 1999). This species-rich group comprises the main invertebrate scavengers and predators in this suspension-feeder-dominated environment (Fedra et al. 1976). Many are very sensitive to hypoxia and $\mathrm{H}_{2} \mathrm{~S}$ (Theede et al. 1969, Vaquer-Sunyer \& Duarte 2008). We hypothesize that crustaceans will be among the first organisms to respond to low DO values and can therefore serve as indicators of developing hypoxia. We also hypothesize that different lifestyles will be reflected in differentiated responses and mortality times, with certain species functioning as early warning signals. We deployed the EAGU (experimental anoxia generating unit) (Stachowitsch et al. 2007) to investigate detailed behavioural responses, intra- and interspecific interactions, and mortalities in the natural environment. The $\mathrm{DO}$ and $\mathrm{H}_{2} \mathrm{~S}$ sensor data allowed individual behaviour - and community-level responses - to be linked to specific thresholds.

\section{MATERIALS AND METHODS}

Study site. The study area is situated approximately $2.3 \mathrm{~km}$ off Cap Madona (Piran, Slovenia) in the Gulf of Trieste $\left(45^{\circ} 32^{\prime} 55.68^{\prime \prime} \mathrm{N}, 13^{\circ} 33^{\prime} 1.89^{\prime \prime} \mathrm{E}\right)$ close to the oceanographic buoy of the Marine Biology Station Piran at a depth of $24 \mathrm{~m}$.

The northern Adriatic Sea is a shallow (mean depth $35 \mathrm{~m}$ ), semi-enclosed ecosystem with highly variable oceanographic and biological conditions due to the combined influence of freshwater discharges, mainly from the Po River, and meteorological and climatic conditions (Justić et al. 1993). These factors govern circulation and lead to summer water-column stratification, hindering oxygen exchange between surface and bottom water (Degobbis et al. 1995, Supić et al. 2002). During periods of persistent stratification, DO drops rapidly in the bottom water due to respiration, benthic recycling of nutrients, and bacterial decomposition (Zavatarelli et al. 1998, Russo et al. 2005).

The poorly sorted silty sand in the study area is colonized by a diverse infauna and high-biomass macroepibenthic assemblages forming so-called multispecies clumps or bioherms (Fedra et al. 1976). These bioherms consist of sessile species, mostly sponges, ascidians, anemones, serpulids, and bivalves growing on hard substrata such as shells. The bioherms, in turn, harbor semi-sessile and vagile organisms such as brittle stars and crustaceans (Zuschin et al. 1999). The community is dominated by filter- and suspension feeders and occupies about $40 \%$ of the Gulf of Trieste. It was described as the 'ORM' community based on the most dominant genera: the brittle star Ophiothrix quinquemaculata, the sponges Reniera spp., and the ascidians Microcosmus spp. (Fedra et al. 1976). Bioherm distribution is patchy on a background of low epifaunal density, represented mainly by mobile deposit-feeding or carnivorous species such as holothurians or hermit crabs (Zuschin \& Stachowitsch 2009).

Experimental design and sampling. The EAGU consists of 2 interchangeable cubic bases, i.e. an opensided aluminium frame and a plexiglas-walled chamber, both measuring $50 \times 50 \times 50 \mathrm{~cm}$ (see Stachowitsch et al. 2007 for detailed description). An instrument lid, placed on top of either of the 2 bases, houses a digital time-lapse camera, 2 flashes, and a datalogger with a microsensor array to record oxygen, $\mathrm{H}_{2} \mathrm{~S}$, and temperature (Unisense ${ }^{\circledR}$ ). The Clark-type microsensors measure a current that reflects the partial pressure of the sulphide species $\mathrm{H}_{2} \mathrm{~S}$ and oxygen at the sensor tip. The 2 oxygen sensors were positioned at 2 and $20 \mathrm{~cm}$ above the sediment in order to detect potential oxygen gradients, and the $\mathrm{H}_{2} \mathrm{~S}$ sensor was positioned $2 \mathrm{~cm}$ above the sediment. $\mathrm{pH}$ was measured once a day with a WTW TA 197-pH sensor. Sensor values were logged every minute, and images were taken every 6 min.

Initially, the 'open' configuration (aluminium frame plus lid) was positioned above a bioherm $\left(0.25 \mathrm{~m}^{2}\right.$ area $)$ to document behaviour under normoxic conditions for $24 \mathrm{~h}$. In the second step, the 'closed' configuration, the frame was exchanged for the chamber, which was repositioned over the same assemblage to document responses to decreasing DO. The chamber sealed off the enclosed water body, and oxygen depletion was induced solely by respiration by the enclosed fauna. After anoxia set in, the deployments were continued for another 1 to $2 \mathrm{~d}$ to document the reaction of less sensitive species. All remaining living and dead organisms were then collected and preserved in a $4 \%$ formalin:seawater solution for species and biomass determination.

Nine out of 13 deployments contained biohermassociated crustaceans and were evaluated here (Table 1). The overall documentation time of all 9 deployments was $832.2 \mathrm{~h}$ (158.6 h open, $673.6 \mathrm{~h}$ closed configuration), encompassing 8322 images. The fieldwork was conducted in September 2005 and from July to October 2006.

Investigated taxa. The present study focused on crustaceans associated with bioherms: Pisidia longimana (Risso, 1816), Pilumnus spinifer (H. Milne-Edwards, 
Table 1. Deployment overview. No.: number of deployment; OC: open configuration; CC: closed configuration

\begin{tabular}{|c|c|c|c|c|c|c|c|c|c|c|}
\hline \multirow[t]{2}{*}{ No. } & \multirow{2}{*}{$\begin{array}{c}\text { Date } \\
\text { (d.mo.yr) }\end{array}$} & \multicolumn{2}{|c|}{ Duration (h) } & \multicolumn{2}{|c|}{$\mathrm{pH}$} & \multirow{2}{*}{$\begin{array}{l}\text { Temp. } \\
\left({ }^{\circ} \mathrm{C}\right)\end{array}$} & \multicolumn{2}{|c|}{ Crustacean abundance } & \multicolumn{2}{|c|}{ Biomass ( $\mathrm{g}$ wet wt $0.25 \mathrm{~m}^{-2}$ ) } \\
\hline & & $\mathrm{OC}$ & $\mathrm{CC}$ & $\mathrm{OC}$ & $\mathrm{CC}$ & & Species & Individuals & Total & Crustacean \\
\hline 2 & $17-22.09 .05$ & - & 132.8 & 8.2 & - & 18.5 & 4 & 57 & 436.7 & 1.7 \\
\hline 6 & $05-08.08 .06$ & 22.4 & 48.3 & 8.2 & 7.9 & 18.8 & 5 & 48 & - & 5.3 \\
\hline 7 & $17-21.09 .06$ & 20.9 & 72.1 & 8.1 & 7.7 & 19.7 & 2 & 20 & 839.8 & 3.3 \\
\hline 8 & $21-24.09 .06$ & 21.7 & 41.9 & 8.2 & - & 20.4 & 6 & 25 & 526.3 & 0.9 \\
\hline 9 & $25-29.09 .06$ & 21.9 & 73 & 8.2 & 7.8 & 20.6 & 2 & 36 & 648.9 & 1.2 \\
\hline 10 & $29.09-02.10 .06$ & 22.7 & 40.3 & 8.2 & 7.9 & 21.4 & 2 & 14 & 629.2 & 0.9 \\
\hline 11 & 05-10.10.06 & 23.6 & 95.4 & 8.2 & 7.5 & 21.3 & 4 & 51 & 724.0 & 4.9 \\
\hline 12 & $10-14.10 .06$ & 25.4 & 75.2 & 8.3 & 7.8 & 21.3 & 3 & 17 & 631.6 & 1.1 \\
\hline 13 & $17-21.10 .06$ & - & 94.6 & 8.3 & 7.8 & 20.4 & 6 & 36 & 1042.7 & 8.3 \\
\hline
\end{tabular}

1834), Eurynome aspera (Pennant, 1777), Macropodia spp., Galathea spp., Inachus spp., and the mutualistic Nepinnotheres pinnotheres (Linnaeus, 1758); but it also included Ebalia tuberosa (Pennant, 1777) and Ethusa mascarone (Herbst, 1785), which mainly inhabit sediment areas. The former buries itself in the sediment during the day (Schembri 1979), the latter carries shells or other objects on its carapace for protection.

From each specimen, size $( \pm 0.1 \mathrm{~mm})$ and wet weight were determined $( \pm 0.01 \mathrm{mg})$. For decomposed individuals, values were estimated from the images using formulas from the literature (see Haselmair 2008 for details). Juveniles and adults were distinguished according to Wurzian (1982) and Pallas et al. (2006).

Data analysis. The behaviours of each individual crab to declining DO and increasing $\mathrm{H}_{2} \mathrm{~S}$ concentrations were analysed image by image and recorded in categories (general and species-specific categories of behaviours and responses' are listed below). This was done for all crustaceans, except for the small and very abundant Pisidia longimana, where 4 larger and conspicuous individuals were selected.

General categories of behaviours and responses:

- Visible presence: sub-categories: completely hidden, partly visible (animal still protected), exposed

- Locomotion: change in location (>1 body length). Sub-categories: minor (1 to 3 body lengths) and major ( $>3$ body lengths) locomotion both in vertical and horizontal directions

- Movement: activity without significant displacement. Sub-categories: turns (changes in direction), body movement ( $<1$ body length), extremity movement

- Atypical posture: posture not observed under normoxia.

- Vertical position: 'ground' (on sediment), 'middle' (up to $5 \mathrm{~cm}$ ), and 'high' (>5 cm above sediment)

- Atypical substrate: use of vagile organisms as a substratum

- Altered predator-prey relationship: predators fail to attack nearby prey, or prey does not flee from approaching predators

- Atypical aggregation: assemblage of more than 3 organisms (at least 1 per crustacean) in direct contact Species-specific categories:

- Camouflage discarded: Ethusa mascarone discards shell carried on its back

- Host abandoned: Nepinnotheres pinnotheres leaves its ascidian host

The images were evaluated as long as the animal was visible and clearly identifiable. The time of mortality was defined as the last activity observed, and the duration of hypoxia until death was determined.

For statistical analyses, oxygen data were assigned to 5 DO categories: normoxia $\left(\geq 2.0 \mathrm{ml} \mathrm{l}^{-1}\right)$, mild hypoxia (2.0 to $1.0 \mathrm{ml} \mathrm{l}^{-1}$ ), moderate hypoxia (1.0 to $\left.0.5 \mathrm{ml} \mathrm{l}^{-1}\right)$, severe hypoxia $\left(<0.5 \mathrm{ml} \mathrm{l}^{-1}\right)$, and anoxia $\left(0 \mathrm{ml} \mathrm{l}^{-1}\right)$. The duration of hypoxia tolerated, differences in lethal DO and $\mathrm{H}_{2} \mathrm{~S}$ concentrations as well as differences in behaviour between oxygen categories were tested using the non-parametric Kruskal-Wallis test. The Mann-Whitney $U$-test was chosen to test which oxygen categories are different from each other regarding single behaviours and to test differences between 2 taxa or deployments. The non-parametric Spearman's rank correlation was used to analyse whether the appearance of Pisidia longimana follows a diurnal rhythm during normoxia. Kendall partial rankorder correlation was chosen to investigate the association between decreasing DO and frequencies of the appearance of $P$. longimana during hypoxia and anoxia. The significance level in all tests was $\mathrm{p}<0.05$. Statistical analysis was performed using the software package SPSS 16.0 for Mac.

\section{RESULTS}

\section{Sensor data}

The EAGU induced anoxia within 1 to $3 \mathrm{~d}$ (Fig. 1). In deployments $6,7,8,10,11$, oxygen declined rapidly, and anoxia was reached within 17.4 to $33.5 \mathrm{~h}$. In all other deployments, anoxia was generated within 51.7 
to $69.8 \mathrm{~h}$ (except for deployment 2, with an intermediate oxygen peak). The rapidity of oxygen decline had no influence on hypoxia-related behaviours but did affect mortality thresholds.

During each open configuration, DO concentrations remained relatively constant and the curves of the 2 sensors were parallel. Overall, the values ranged from 2.6 to $5.6 \mathrm{ml} \mathrm{l}^{-1}$ on the bottom and from 2.8 to $8.9 \mathrm{ml} \mathrm{l}^{-1}$ $20 \mathrm{~cm}$ above the sediment. Values measured $20 \mathrm{~cm}$ above the sediment were typically higher than those directly above the sediment (exceptions: deployments 6 and 7 ). The values of the 2 sensors during the open configuration differed less during calm $\left(0.3 \mathrm{ml} \mathrm{l}^{-1} \mathrm{DO}\right)$ than during stormy weather (1.92 $\left.\mathrm{ml} \mathrm{l}^{-1} \mathrm{DO}\right)$. During the closed configuration, DO values dropped immediately and continuously. Both curves then approximated each other, but values typically remained slightly higher above than at the sediment until anoxia occurred.

Soon after anoxia occurred, $\mathrm{H}_{2} \mathrm{~S}$ concentrations rose steadily up to $21 \mu_{\mathrm{mol}} \mathrm{l}^{-1}$ in deployments with brief anoxia $(6,8,9,10,12)$ and up to $304 \mu \mathrm{mol} \mathrm{l}^{-1} \mathrm{H}_{2} \mathrm{~S}$ when anoxia persisted for at least $2 \mathrm{~d}(2,7,11,13)$.

Temperature remained nearly constant during a particular deployment and was similar between deployments (18.5 to $21.4^{\circ} \mathrm{C}$; Table 1$)$. Bottom water salinity was $38 \%$. Bottom water $\mathrm{pH}$ values during the open configuration were constant (8.1 to 8.3) and decreased to a minimum of 7.5 inside the chamber (deployment 11; Table 1).

\section{Abundance and biomass}

Three of the 9 investigated species were abundant and present in most deployments: Pisidia longimana ( $\mathrm{n}=265$, average 29.4 ind. $0.25 \mathrm{~m}^{-2}$ ); Pilumnus spinifer ( $\mathrm{n}=17$, average 1.9 ind. $0.25 \mathrm{~m}^{-2}$ ), and Macropodia spp. ( $\mathrm{n}=7$, average 0.8 ind. $0.25 \mathrm{~m}^{-2}$ ) the others were represented by only 2 or 3 individuals each. The distribution of species across the deployments varied between 2 and 6 species. Three Galathea spp. were counted, but more were probably present.

Based on size, most individuals were adults. Juveniles of Pilumnus spinifer, Macropodia spp., and Pisidia longimana were present. The 2 female Nepinnotheres pinnotheres, both inhabiting an ascidian, were immature.

Epibenthic biomass in the chambers was high (mean $685 \mathrm{~g}$ wet wt $0.25 \mathrm{~m}^{-2}$ ), largely because we specifically targeted multi-species clumps rather than free sediment surfaces. Mean crustacean biomass was $3.1 \mathrm{~g}$ wet wt $0.25 \mathrm{~m}^{-2}$, ranging from 0.9 to $8.3 \mathrm{~g}$ wet wt $0.25 \mathrm{~m}^{-2}$ within deployments, with the small and abundant Pisidia longimana accounting for about $28 \%$. Crustaceans made up only $0.4 \%$ of total epifaunal biomass. These values agree with those reported in Wurzian (1982) and Fedra et al. (1976), although the observed density and biomass of Pilumnus spinifer and $P$. longimana here were considerably higher.

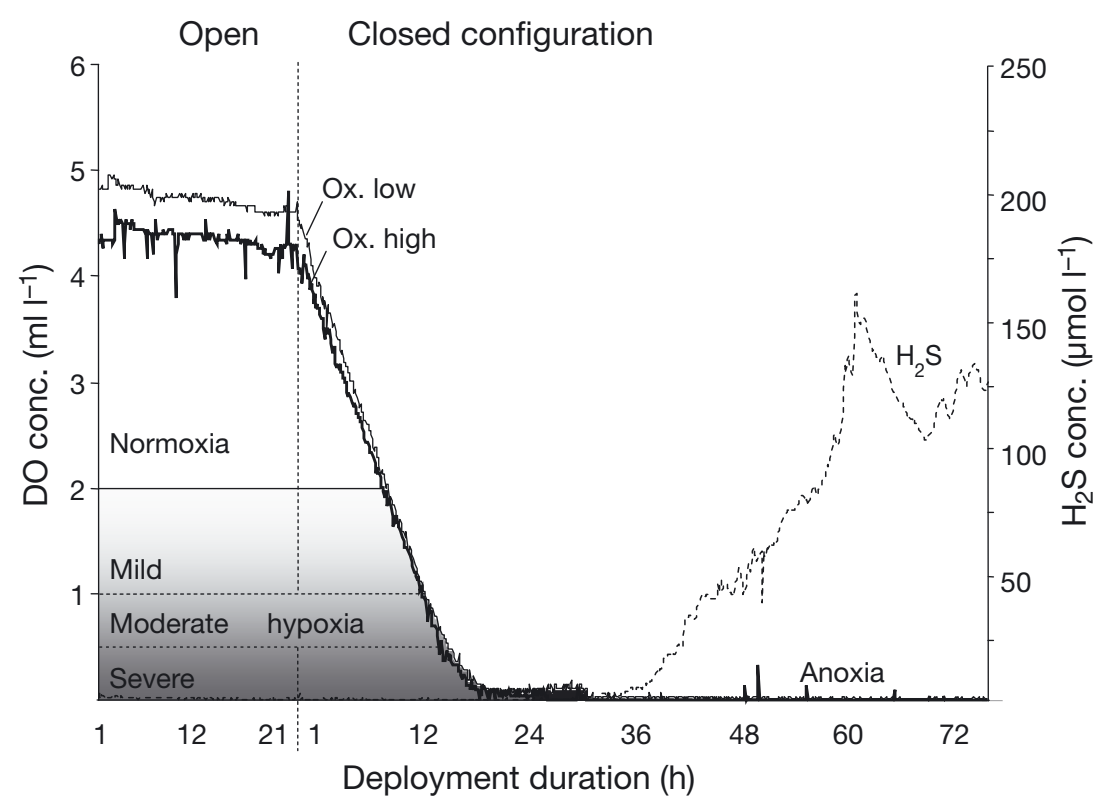

Fig. 1. Characteristic sensor data (deployment 7). White area under oxygen curve: normoxia; grey area: hypoxia. Threshold values for different stages of hypoxia indicated with dashed lines at 1 and $0.5 \mathrm{ml} \mathrm{l}^{-1}$ dissolved oxygen (DO). Ox. low: values $2 \mathrm{~cm}$ above sediment; ox. high: values $20 \mathrm{~cm}$ above sediment $\left(\mathrm{ml} \mathrm{l}^{-1}\right) ; \mathrm{H}_{2} \mathrm{~S}$ : values $2 \mathrm{~cm}$ above sediment $\left(\mu \mathrm{mol} \mathrm{l^{-1 }}\right)$

\section{Behavioural responses}

All species displayed a succession of behavioural patterns related to declining oxygen values (Fig. 2). Combinations of behaviours often occurred, and the timing of the responses varied interspecifically and, to a lesser degree, intraspecifically.

\section{Avoidance}

During normoxia, crustaceans were hidden from view in at least $83 \%$ of all observations because of their cryptic lifestyle or camouflage (Fig. 3). An exception was the majoidean crabs (Macropodia spp., Inachus sp., and Eurynome aspera). As oxygen decreased, their visibility increased significantly. Pilumnus spinifer, for example, was hidden $54 \%$ of the time during mild, $23 \%$ during moderate, and only $4 \%$ during 


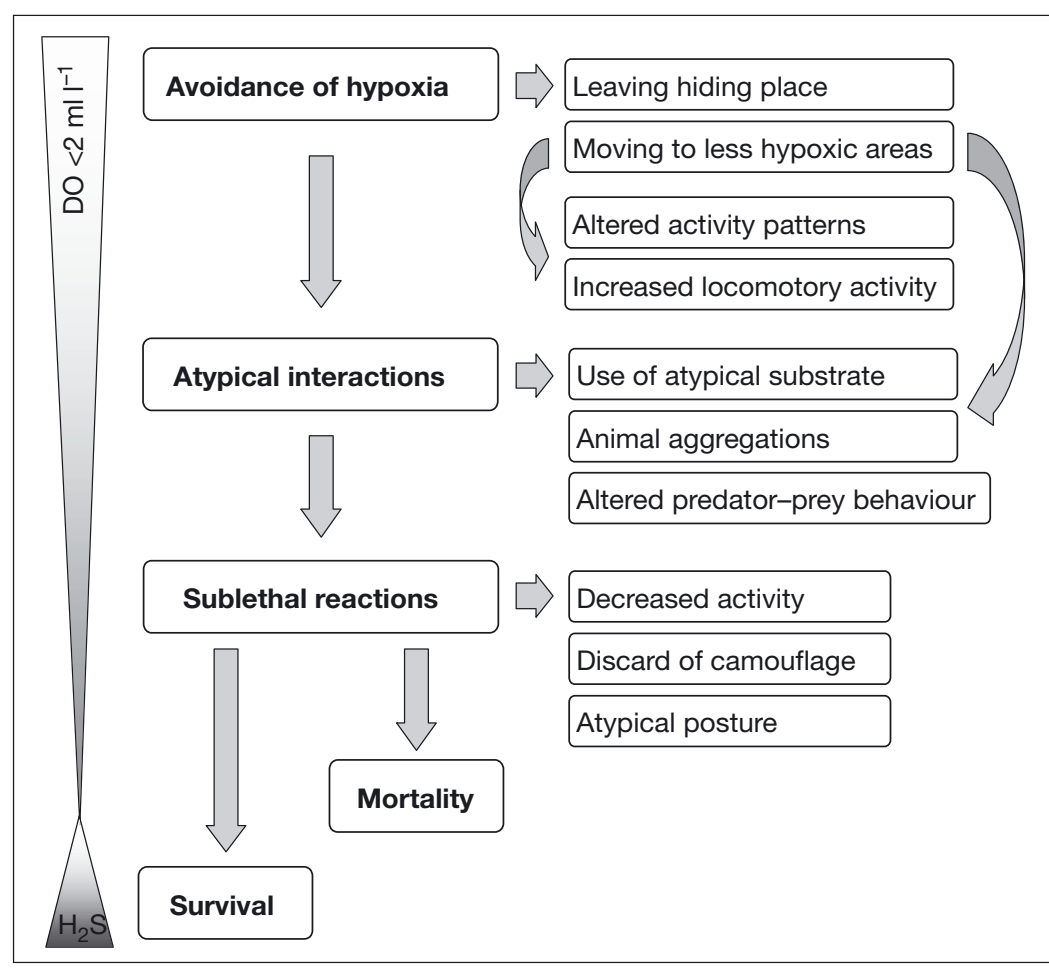

Fig. 2. Crustacean responses to decreasing DO values. Note that responses are elicited at different DO concentrations depending on species. Most atypical behaviours and mortalities were induced prior to $\mathrm{H}_{2} \mathrm{~S}$ evolution quartile] $=0.98 / 0.92) ; 50 \%$ were visible at values below $0.65 \mathrm{ml} \mathrm{l}^{-1} \mathrm{DO}$ $\left(\mathrm{Q}_{1} / \mathrm{Q}_{3}=0.77 / 0.53\right)$, and $100 \%$ at severe hypoxia, i.e. $0.34 \mathrm{ml} \mathrm{l}^{-1} \mathrm{DO}$ $\left(Q_{1} / Q_{3}=0.38 / 0.30\right)$. Normal nighttime activity masks hypoxia-induced emergence in deployments with hypoxia setting in at night. Usually about half of the individuals were visible simultaneously during any night; higher values point to a hypoxia effect. The median DO value for $100 \%$ of animals visible during nighttime hypoxia onset $\left(0.24 \mathrm{ml} \mathrm{l}^{-1} \mathrm{DO}, \mathrm{Q}_{1} / \mathrm{Q}_{3}=\right.$ $0.4 / 0.18$ ) also corresponds well with the daytime equivalent.

Hypoxic stress triggered a typical sequence of locomotory activity (locomotion, body, and extremity movement) in all species after emergence: a locomotion peak at the onset of hypoxia, a rapid decline during severe hypoxia, followed by inactivity during anoxia (Fig. 3). Nepinnotheres pinnotheres and Ebalia tuberosa differed: both continued to move during anoxia (in 50 and $60 \%$ of all observations, respectively; Fig. 3), when most severe hypoxia. This pattern was similar for Galathea spp. and Pisidia longimana. Ethusa mascarone began to move at moderate hypoxia. The 3 Ebalia tuberosa emerged from the sediment at $1.38,0.63$, and $0.45 \mathrm{ml} \mathrm{l}^{-1}$ DO. While all other species were already visible or dead during anoxia, Nepinnotheres pinnotheres remained hidden within its host until anoxia. One specimen emerged after $11.7 \mathrm{~h}$ of hypoxia and $13.6 \mathrm{~h}$ of anoxia, the other after $53.2 \mathrm{~h}$ of hypoxia and $19.4 \mathrm{~h}$ of anoxia. The corresponding $\mathrm{H}_{2} \mathrm{~S}$ concentrations were 18.3 and $93.9 \mu \mathrm{mol} \mathrm{l} \mathrm{l}^{-1}$.

Crustaceans showed an activity peak at night. For Pisidia longimana (Fig. 4), for example, the correlation between the circadian rhythm and the percentage of visible animals was strong and significant (Spearman's $\mathrm{r}_{\mathrm{S}}$ : 0.829; $\mathrm{p}<0.001$ ), whereas DO values and visible presence were initially not correlated. During mild hypoxia, normal patterns (daytime hiding) persisted, but from moderate hypoxia on, all individuals became visible permanently. The correlation with DO concentrations then became strong and significant (Kendall's $\tau$ : $0.8851 ; \mathrm{p}<0.001)$. All individuals emerged between 0.96 and $0.24 \mathrm{ml} \mathrm{l}^{-1}$ DO (medians, calculated for each deployment separately).

When hypoxia set in during the day, the first Pisidia longimana were visible at moderate hypoxia (median DO concentration of $0.96 \mathrm{ml} \mathrm{l}^{-1} ; \mathrm{Q}_{1} / \mathrm{Q}_{3}$ [first and third other crabs were moribund or dead. $N$. pinnotheres was most active at anoxia, whereas E. tuberosa showed only body movements rather than locomotion.

When active during normoxia, crustaceans spent $65 \%$ of their time on the sediment (Fig. 5), except Pisidia longimana and Macropodia spp., which largely remained on bioherms. Hypoxia induced all crustaceans to move to more oxygenated areas. Most species immediately climbed onto the next bioherm or higher up on the bioherm they inhabited during mild hypoxia. Eurynome aspera, Ebalia tuberosa, and Ethusa mascarone initially tried to escape horizontally on the sediment, then vertically. During mild hypoxia, crustaceans were on elevated sites in $64 \%$ of all observations, rising to $83 \%$ during moderate hypoxia (Fig. 5). Even those species that rarely (E. aspera and Inachus sp.) or never (E. tuberosa and E. mascarone) occurred on bioherms during normoxia, started to move up as DO $( \pm \mathrm{SD})$, fell below $1.16( \pm 0.6)$ and $0.15( \pm 0.1) \mathrm{ml}^{-1}$, respectively. At values persistently below $0.49( \pm 0.32) \mathrm{ml} \mathrm{l}^{-1} \mathrm{DO}$, Pilumnus spinifer positioned itself at the highest place. One E. mascarone climbed up a sensor and disappeared from view. Ultimately, crustaceans left or dropped from their elevated perches and died on the sediment. Moribund animals apparently were unable to hold onto bioherms. Five of 8 Macropodia spp. and 1 Inachus sp. were dragged down by falling brittle stars. 


\section{Atypical interactions and sublethal responses}

At normoxia, most crustaceans typically avoided each other. With decreasing oxygen concentrations, however, intra- and interspecific interactions gradually increased in number and duration. A common response during mild hypoxia was climbing on top of vagile or- ganisms such as holothurians, echinoids, or ophiuroids, which are normally not used as a substratum (Fig. 6a). The most frequent interaction response was a diminished distance between individuals of one or different species. During mild hypoxia, dominant individuals of Pilumnus spinifer chased subordinate individuals or other crabs such as Macropodia spp. away. This behav-

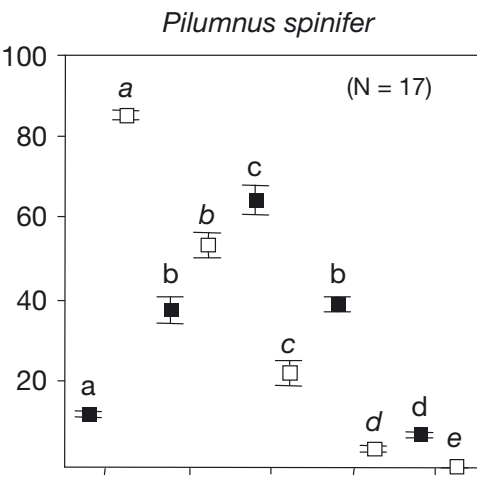

Nepinnotheres pinnotheres

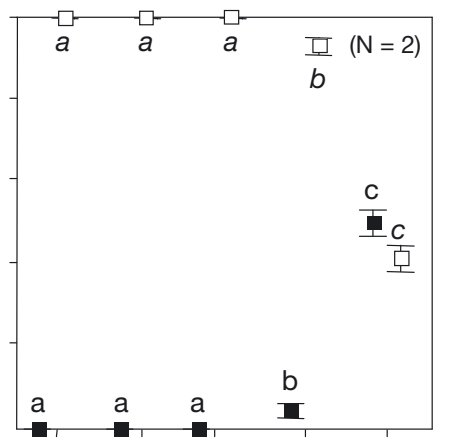

$\mathrm{N}=4993 \quad 993 \quad 760 \quad 3507 \quad 5617 \quad \mathrm{~N}=460$

101101
Macropodia spp.

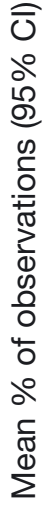

Galathea spp.

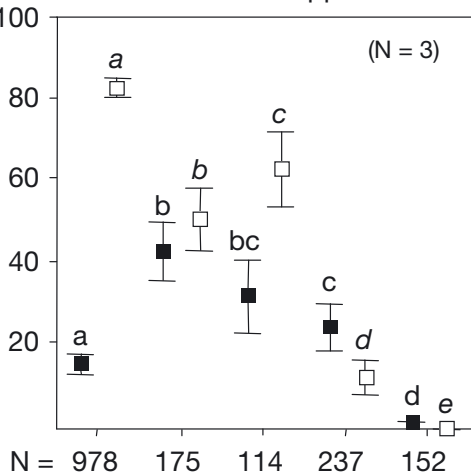

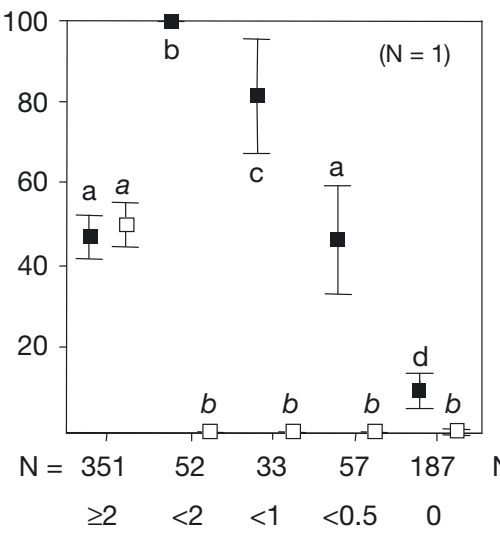
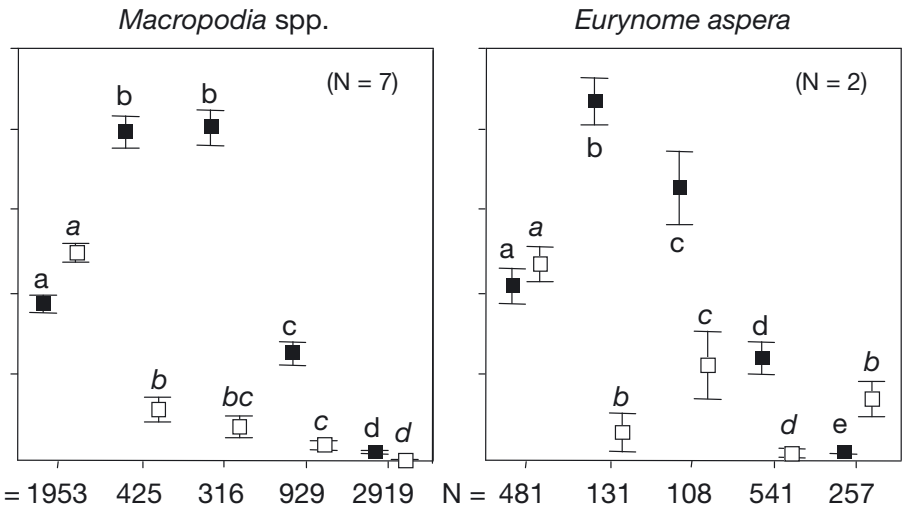

Ebalia tuberosa

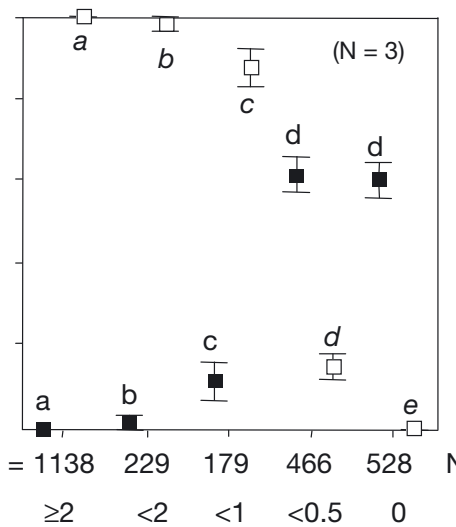

Ethusa mascarone

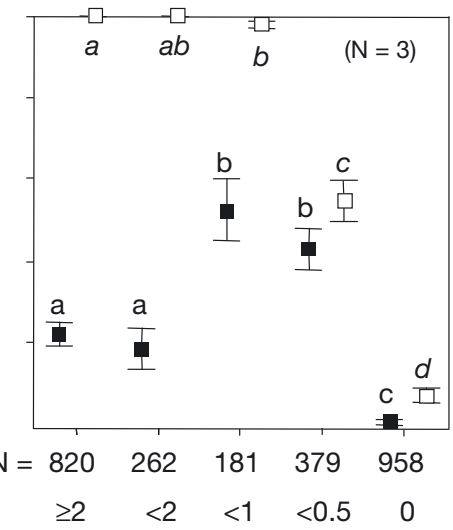

DO conc. category ( $\left.\mathrm{ml} \mathrm{l}^{-1}\right)$

Fig. 3. Species-specific changes in hiding behaviour $(\square)$ and locomotory activity ( $\square$ ) in the 5 oxygen categories. Beyond visible presence, the following specific reactions were considered: Nepinnotheres pinnotheres, abandoning its host; Ebalia tuberosa, emerging from sediment; Ethusa mascarone, dropping its protective shell fragment. Numbers below $x$-axes: number of photographs evaluated per oxygen category. Analyses are by Mann-Whitney $U$-tests $(\mathrm{p}<0.05)$. Same letters above error bars indicate no significant difference between means of the respective oxygen categories 


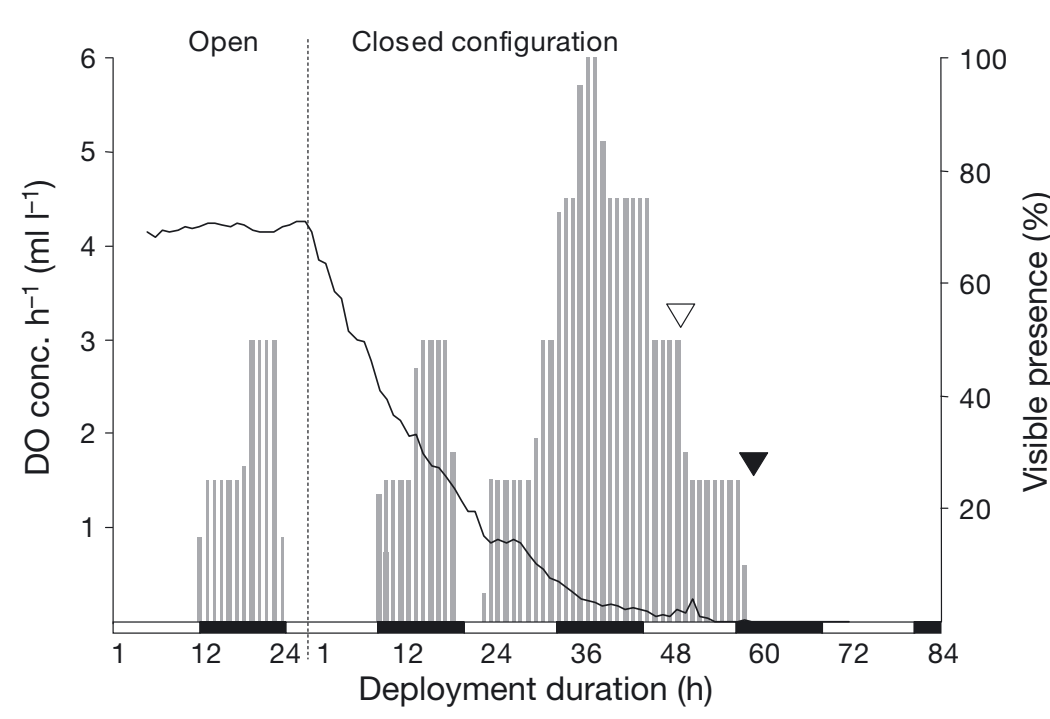

Fig. 4. Visible presence of Pisidia longimana during normoxia, hypoxia, and anoxia in selected deployments. Histograms: average number of observations per hour in relation to oxygen values (lower sensor). White and black arrows: 50 and $100 \%$ mortality, respectively. Dark horizontal bars: night; white horizontal bars: day

iour ceased during severe hypoxia. For example, at DO below $0.43 \mathrm{ml} \mathrm{l}^{-1}$ (deployment 7 ) and below $0.27 \mathrm{ml} \mathrm{l}^{-1}$ (deployment 11), no intra- and interspecific aggression was observed between adjoining individuals. This behaviour, coupled with the restricted availability of higher substrata, resulted in atypical aggregations on the highest, most oxygenated sites. With ongoing hypoxia, aggregation sizes increased to a maximum of 27 crustaceans, mostly Pisidia longimana but also P. spinifer, Macropodia spp., and Eurynome aspera, along with other small organisms (shrimps, brittle stars, or flatworms; Fig. 6b). The greatest number of aggregations as well as the greatest number of individuals in such aggregations occurred during severe hypoxia (Fig. 6a).

Predator-prey relationships changed during severe hypoxia. Brittle stars never positioned themselves close to Pilumnus spinifer during normoxia, but did so during moderate and severe hypoxia. While prey still fled during moderate hypoxia, Pisidia longimana and juvenile brittle stars even climbed on top of potential predators at values below $0.5 \mathrm{ml} \mathrm{l}^{-1} \mathrm{DO}$. One Macropodia spp. fled from $P$. spinifer at $1.2 \mathrm{ml} \mathrm{l}^{-1} \mathrm{DO}$, but showed no escape reaction below $0.9 \mathrm{ml} \mathrm{l}^{-1}$ DO. Another Macropodia spp. fled at $0.6 \mathrm{ml} \mathrm{l}^{-1} \mathrm{DO}$. Conversely, $P$. spinifer or Ebalia tuberosa did not attack nearby prey (juvenile brittle stars, small crustaceans).

A common sublethal response was turning over shortly before death, with no righting response ever being observed thereafter. Among the species-specific sublethal responses, Ethusa mascarone discarded its camouflage at $0.4,0.23$, and $0.03 \mathrm{ml} \mathrm{l}^{-1}$ DO. One individual was predated by the anemone Calliactis parasitica shortly (1.3 h) after discarding its protective shell at $0.4 \mathrm{ml} \mathrm{l}^{-1} \mathrm{DO}$ and zero $\mathrm{H}_{2} \mathrm{~S}$.

\section{Mortality and survival}

Mortality increased significantly during severe hypoxia and continued during anoxia ( $\mathrm{p}<0.001$; Fig. 7a). Overall, $97 \%$ of all investigated individuals died, $54 \%$ of those during severe hypoxia, with Galathea spp., Macropodia spp., and Pisidia longimana among the first (Fig. 7b). Most crustaceans died before $\mathrm{H}_{2} \mathrm{~S}$ values began to rise. A total of $22 P$. longimana individuals and 1 Macropodia sp. died at low $\mathrm{H}_{2} \mathrm{~S}$ concentrations

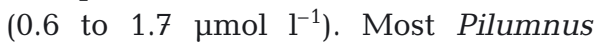
spinifer survived lower $\mathrm{H}_{2} \mathrm{~S}$ concentrations $\left(<72.8 \mu \mathrm{mol} \mathrm{l}^{-1}\right.$; Table 2).

Pisidia longimana and Pilumnus spinifer, for example, died at significantly different mean $( \pm \mathrm{SD})$ DO concentrations $(0.1 \pm 0.12$ and $0.01 \pm 0.01 \mathrm{ml} \mathrm{l}^{-1}$, respectively; $\left.\mathrm{p}=0.004\right)$. The duration of hypoxia/anoxia that caused mortality also differed significantly between $P$. longimana and $P$. spinifer $(\mathrm{p}=0.001)$ and between $P$. spinifer and Macropodia spp. $(\mathrm{p}<0.001)$. The mean post-normoxia survival time for Macropodia spp. was $17.8 \pm 2.7 \mathrm{~h}$, for $P$. longimana $22.5 \pm 8.3 \mathrm{~h}$, and for $P$. spinifer $32.5 \pm$

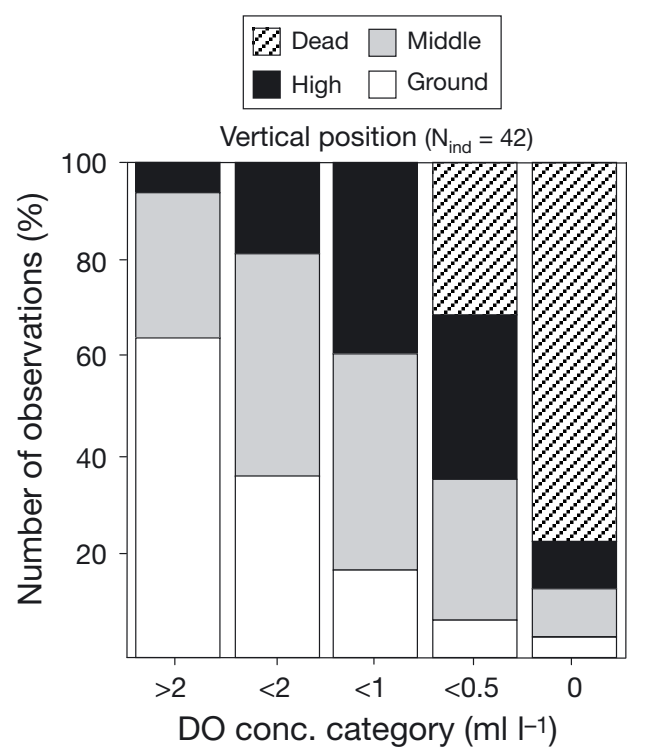

Fig. 5. Changes in vertical position (all species; $\mathrm{n}=42$ ) in the 5 oxygen categories. Percentage of observations of specimens positioned at different heights (ground: on sediment; middle: up to $5 \mathrm{~cm}$; high: $>5 \mathrm{~cm}$ above sediment) 
$9.6 \mathrm{~h}$. The duration and severity of oxygen depletion influenced mortality thresholds. In deployments with a slow oxygen decline, $P$. longimana died at significantly higher concentrations $\left(0.17 \pm 0.15 \mathrm{ml} \mathrm{l}^{-1} \mathrm{DO}\right)$ than in those with a rapid decline $\left(0.06 \pm 0.07 \mathrm{ml} \mathrm{l}^{-1} \mathrm{DO}\right)(\mathrm{p}<$ 0.001), a trend also shown by Macropodia spp. and P. spinifer.

Five individuals of 3 species survived (Fig. $7 \mathrm{~b}$ ). One Pilumnus spinifer and 2 Ebalia tuberosa were high up on a sponge but moribund at the end of the deployment. Both Nepinnotheres pinnotheres individuals survived extended oxygen depletion and high $\mathrm{H}_{2} \mathrm{~S}$ concentrations (Table 2) and continued to show very active horizontal and vertical locomotion.

\section{DISCUSSION}

\section{Sensor data and biomass}

The EAGU system captured the typical normoxic DO conditions during late summer and autumn in the northern Adriatic Sea and effectively created hypoxia and anoxia and promoted $\mathrm{H}_{2} \mathrm{~S}$ production. The occasionally low DO concentrations in the open configuration (minimum $2.6 \mathrm{ml} \mathrm{l}^{-1}$ ) agree with previously recorded near-bottom autumn values (Stachowitsch
1991, Artegiani et al. 1997) and reflect the high oxygen demand of bacterial remineralisation and benthic respiration in periods with stratification (Herndl et al. 1989). Fluctuating concentrations and peak values reflect vertical mixing due to storms (Russo et al. 2005). Although DO concentrations are expected to be higher $20 \mathrm{~cm}$ above the sediment than directly at the bottom (Dade et al. 2001), in 2 deployments a reverse situation was observed. We attribute this to complex current patterns (open configuration) and to ventilation by burrowing organisms (closed configuration). The latter effect would be negligible in large-scale anoxia. The drop in $\mathrm{pH}$ values from 8.2 to 7.5 should not directly affect the epifauna (Knutzen 1981) but shifts the sulphide equilibrium towards $\mathrm{H}_{2} \mathrm{~S}$ (Jeroschewski et al. 1996).

\section{Behavioural responses}

Most investigations on the responses and adaptations of crustaceans to hypoxia and $\mathrm{H}_{2} \mathrm{~S}$ concentrations were conducted in laboratory settings and focused on physiological responses (Airriess \& McMahon 1994, Vismann \& Hagerman 1996, Burnett \& Stickle 2001). Our approach yielded a full range of behavioural responses in a community-level setting. All crus-

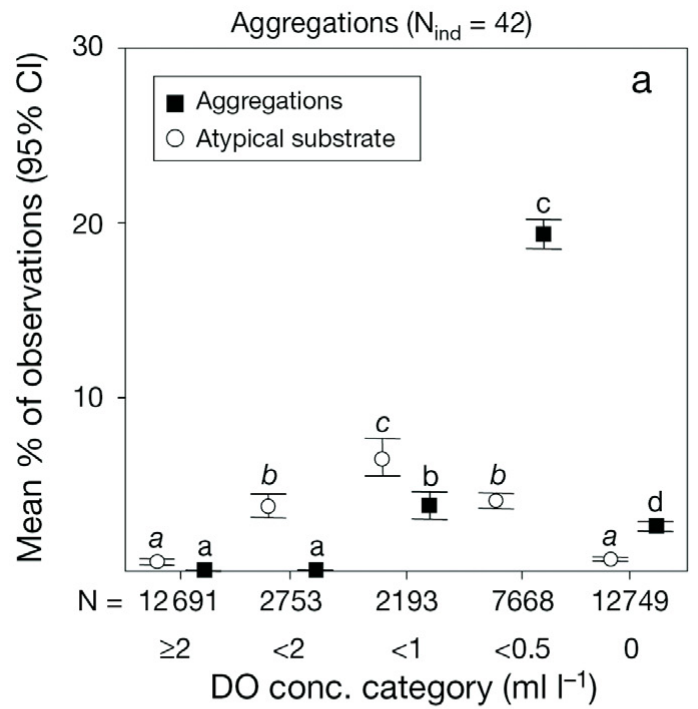

Fig. 6. (a) Mean percentage of observations of aggregations (匹) and of investigated specimens atypically using vagile species as substrates (O) with $95 \%$ confidence intervals (all deployments). $\mathrm{n}=$ number of investigated individuals. See Fig. 3 for further details. (b) Aggregation during severe hypoxia (de-

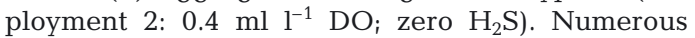
Pisidia longimana aggregate on Phallusia mammillata and on other parts of the bioherm. One Pilumnus spinifer and 2 shrimps are visible on the ascidian

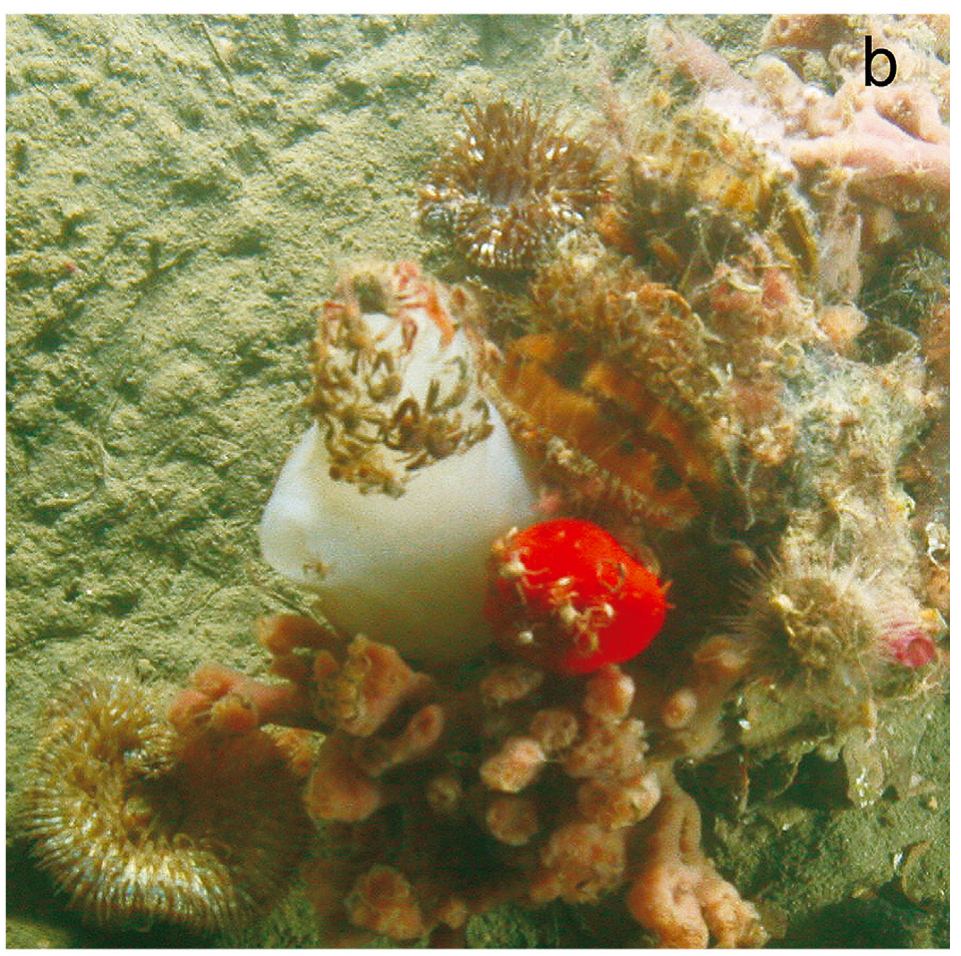



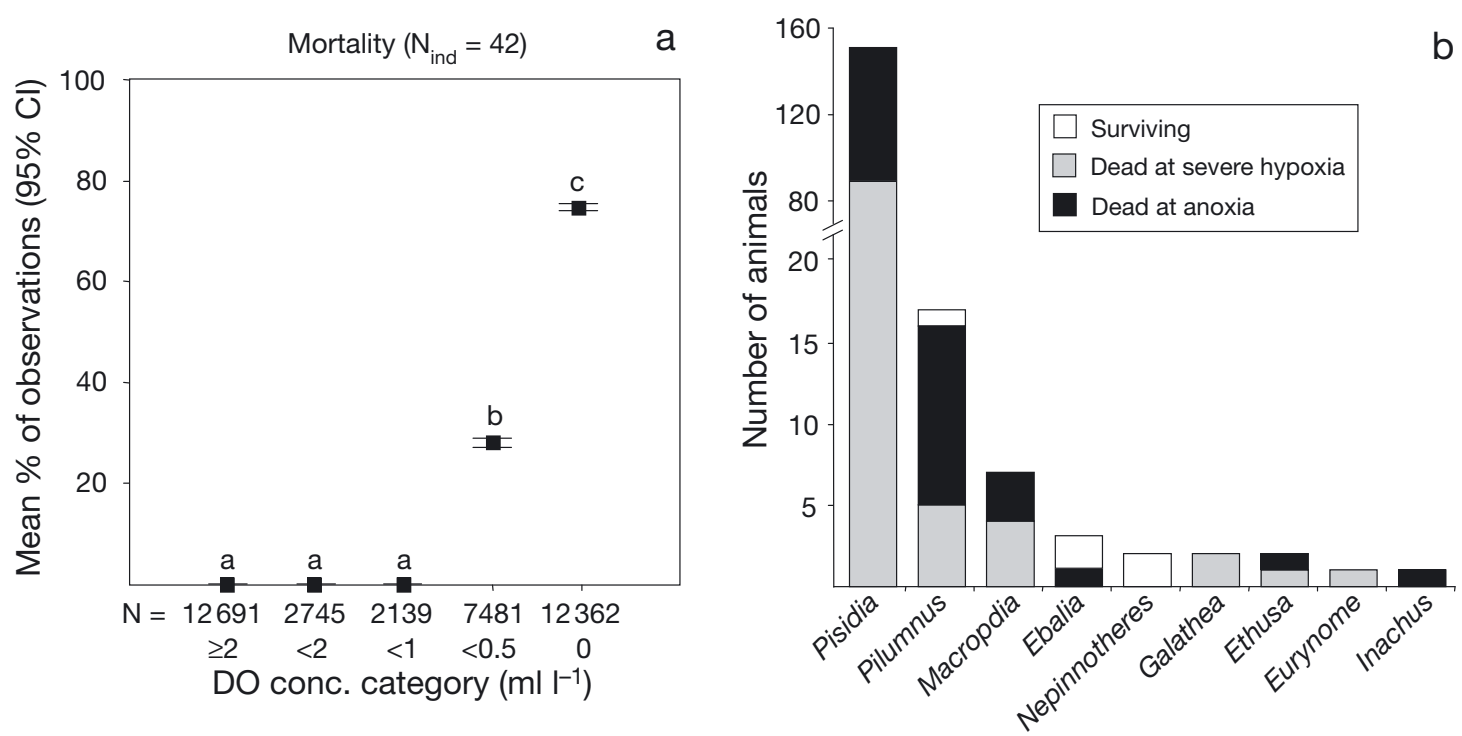

Fig. 7. (a) Mean percentage of observations of dead crustaceans during the 5 oxygen categories. All deployments evaluated. See Fig. 3 for further details. (b) Numbers of individuals of each taxon dying at severe hypoxia and anoxia as well as numbers of surviving taxa $(\mathrm{n}=184)$

taceans showed distinct responses and the respective patterns were repeated across deployments. Certain behaviours coincide with the observations reported elsewhere (Renaud 1986, Wannamaker \& Rice 2000); others were previously unreported.

\section{Avoidance}

Avoidance, as an initial response, has been reported in numerous marine species (Pihl et al. 1991, Levin et al. 2009). In Mobile Bay (Alabama, USA) for example, vertical mass migrations of later moribund and easily capturable demersal fish and crustaceans to the shoreline are known as 'jubilees' (May 1973). The direction of escape in our deployments was either vertical or horizontal, probably reflecting the degree of association to bioherms. Based on survival times, all those species that initially fled horizontally were less sensitive to hypoxia. The higher DO concentrations at typical bioherm heights (ca. $20 \mathrm{~cm}$ ) allow crustaceans to survive longer there. Such refuges are therefore important for short-term or near-ground hypoxia but would probably become insignificant at severe, prolonged, and largescale anoxia.

Daytime presence of normally cryptic crustaceans (Pilumnus spinifer, Pisidia longimana, and Galathea spp.) indicates stress. Rosenberg et al. (1991) also observed the abandonment of protected positions in laboratory experiments at species-specific DO thresholds. In our deployments, most species emerged during mild hypoxia (median $1.6 \mathrm{ml} \mathrm{l}^{-1} \mathrm{DO}$ for the majoidean crabs and $1.4 \mathrm{ml} \mathrm{l}^{-1} \mathrm{DO}$ for P. spinifer). Ethusa mas- carone and the less sensitive Ebalia tuberosa maintained their normal activity patterns longer, until moderate and severe hypoxia, respectively. $P$. longimana tended to hide longer than other crustaceans, possibly because such small crabs need to minimise the predation risk as long as possible, as reported for amphipods by Johansson (1997). When intraspecific behaviours were not correlated to one critical DO concentration3 E. tuberosa emerged from the sediment at different stages of hypoxia during the night-normal nocturnal emergence (Schembri 1979) probably masked direct responses to hypoxia. Hypoxia forced all crustaceans to abandon their normal activity patterns regardless of the time of day. Circadian rhythms are widespread in crustaceans (deCoursey 1983, Aréchiga et al. 1993). P. longimana, P. spinifer, and Macropodia spp. are night active, probably a predator avoidance strategy (deGrave \& Turner 1997). We identified $1 \mathrm{ml} \mathrm{l}^{-1} \mathrm{DO}$ as the species-specific threshold for visible presence in $P$. longimana. Once emerged, no crustaceans hid again unless DO temporarily increased (see Riedel et al. 2008b).

Avoidance reactions involved up to threefold greater locomotory activity in all species. Thereafter, activity decreased, typically ending in immobility at severe hypoxia. Such a pattern has also been reported in the blue crab Callinectes sapidus (deFur et al. 1990) and various shrimp species (Hagerman \& Uglow 1984, Renaud 1986). Reduced locomotion is a common strategy to save energy, which is required for respiration (Johansson 1997, Mistri 2004). Declining activity may also involve switching to energyconserving metabolic depression (Wu 2002). Reported 
Table 2. DO and $\mathrm{H}_{2} \mathrm{~S}$ concentrations at time of death or end of deployment (surviving taxa) and the duration of hypoxia and anoxia until death or end of deployment. If $\mathrm{n} \leq 2$, range is replaced by measured value(s). $\mathrm{Q}_{1}$ : first quartile; $\mathrm{Q}_{3}$ : third quartile

\begin{tabular}{|c|c|c|c|c|c|c|c|c|}
\hline \multirow[t]{2}{*}{ Dead taxa } & \multirow[t]{2}{*}{$\mathrm{n}$} & \multicolumn{3}{|c|}{$\mathrm{DO}\left(\mathrm{ml} \mathrm{l}^{-1}\right)$} & \multicolumn{2}{|c|}{ Duration of hypoxia (h) } & \multicolumn{2}{|c|}{$\mathrm{H}_{2} \mathrm{~S}\left(\mu \mathrm{mol} \mathrm{l} \mathrm{l}^{-1}\right)$} \\
\hline & & & $\begin{array}{l}\text { Median } \\
\left(\mathrm{Q}_{1} / \mathrm{Q}_{3}\right)\end{array}$ & Range & $\begin{array}{l}\text { Median } \\
\left(\mathrm{Q}_{1} / \mathrm{Q}_{3}\right)\end{array}$ & Range & $\begin{array}{l}\text { Median } \\
\left(\mathrm{Q}_{1} / \mathrm{Q}_{3}\right)\end{array}$ & Range \\
\hline Pisidia longimana & 150 & & $\begin{array}{c}0.03 \\
(0 / 0.1)\end{array}$ & $0-0.3$ & $\begin{array}{c}21.3 \\
(16.2 / 26.8)\end{array}$ & $9.5-45.0$ & $\begin{array}{c}0 \\
(0 / 0)\end{array}$ & $0-1.68$ \\
\hline Pilumnus spinifer & 16 & & $\begin{array}{c}0 \\
(0 / 0.01)\end{array}$ & $0-0.03$ & $\begin{array}{c}33.0 \\
(23.4 / 37.4)\end{array}$ & $17.1-54.3$ & $\begin{array}{c}1.42 \\
(0 / 10.77)\end{array}$ & $0-72.8$ \\
\hline Macropodia spp. & 7 & & $\begin{array}{c}0 \\
(0 / 0.19)\end{array}$ & $0-0.39$ & $\begin{array}{c}16.4 \\
(15.8 / 19.6)\end{array}$ & $14.9-22.3$ & $\begin{array}{c}0 \\
(0 / 0.005)\end{array}$ & $0-0.84$ \\
\hline Ethusa mascarone & 2 & & - & $0 / 0.4^{\mathrm{a}}$ & - & $30.2 / 10.3^{\mathrm{a}}$ & - & 0 \\
\hline Galathea spp. & 2 & & - & $0.03 / 0.33$ & - & $21.8 / 17.8$ & - & 0 \\
\hline Eurynome aspera & 1 & & & 0.19 & - & 25.1 & - & 0 \\
\hline Inachus sp. & 1 & & & 0 & - & 24.6 & - & 0 \\
\hline \multicolumn{9}{|c|}{${ }^{\mathrm{a} O n e}$ predated animal } \\
\hline Surviving taxa & & $\mathrm{n}$ & $\mathrm{D}$ & $\mathrm{O}\left(\mathrm{ml} \mathrm{l}^{-1}\right)$ & Duration of & 1ypoxia + an & (h) & $\mathrm{H}_{2} \mathrm{~S}\left(\mu \mathrm{mol} \mathrm{l}^{-1}\right)$ \\
\hline P. spinifer & & 1 & & 0 & & $2.7+8.5$ & & 0 \\
\hline Ebalia tuberosa & & 2 & & 0 & $21.8+$ & $4.1 / 34.2+2$ & & 12.8/19.2 \\
\hline Nepinnotheres pinn & & 2 & & 0 & $53.2+$ & $24.6 / 11.7+7$ & & $126.1 / 111.6$ \\
\hline
\end{tabular}

species-specific thresholds for reduced activity are $2 \mathrm{ml} \mathrm{l}^{-1}$ DO for Crangon crangon (Hagerman \& Szaniawska 1986) and juvenile Nephrops norvegicus (Eriksson \& Baden 1997), similar to the thresholds we found for Inachus sp. and Eurynome aspera. Nevertheless, most crustaceans in our study showed a first significant reduction in activity later, i.e. between 1 and $0.5 \mathrm{ml} \mathrm{l}^{-1}$ DO. Two interpretations are possible: a greater tolerance in the natural, structurally complex setting (versus laboratory conditions), or a community composition adapted to low oxygen concentrations.

\section{Atypical interactions and sublethal responses}

Atypical interactions included using atypical substrata, multi-species aggregations, loss of habitat segregation, and altered predator-prey interactions. Examples for sublethal responses are atypical postures and discarding of camouflage.

In the northern Adriatic, the brittle star Ophiothrix quinquemaculata is known to climb onto and hitch rides with holothurians Holothuria tubulosa (Stachowitsch 1979). Crustaceans typically avoid mobile organisms as a substratum. During mild and moderate hypoxia, however, crustaceans crawled on any available structure or organism and formed multi-species aggregations. Intraspecific aggregations are known for non-territorial crustaceans like Pisidia longimana (Pallas et al. 2006), but are reported here for the first time for the highly territorial (Wurzian 1977) Pilumnus spinifer as well. Loss of intraspecific aggression and territorial behaviour has also been described for Mundia quadrispina, but at a much lower threshold $\left(<0.15 \mathrm{ml} \mathrm{l}^{-1} \mathrm{DO}\right.$; Burd \& Brinkhurst 1984). These aggregations signal high hypoxic stress and are an indicator for severe hypoxia.

Hypoxia also affected intraspecific habitat segregation: juvenile majoidean crabs normally hid on bioherms, whereas adults were found on the sediment or hidden beneath an anemone or sponge. At hypoxia, both aggregated on bioherms.

Feeding behaviour and predator-prey interactions were also affected. Pilumnus spinifer normally feeds on small galatheid/porcellanid crabs and juvenile brittle stars (Števčić 1975). The predatory crab determines the distribution of the brittle star Ophiothrix quinquemaculata, which normally maintains at least a 1 to $2 \mathrm{~cm}$ distance or avoids crab-occupied bioherms entirely (Wurzian 1977). If contact is made, brittle stars retract their arms and re-establish a safe distance (Riedel et al. 2008a). At severe hypoxia, however, brittle stars and crabs aggregated together. The absence of predator avoidance is common in oxygen-deficient environments (Johansson 1997) and was also recorded here for Galathea sp. and Pisidia longimana. The behaviour necessary to maintain aerobic respirationexposure on higher substrates-is inappropriate for avoiding predation (Pihl et al. 1991, Mistri 2004). Whether moribund or inactive individuals are easy 
prey depends on the relative hypoxic sensitivity of predator and prey. Hypoxia affects predator-prey interactions to the benefit of the more tolerant species (Sagasti et al. 2001). Predators may be less tolerant, in which case potential prey can attain a partial refuge at low oxygen concentrations (Sandberg 1994, Taylor \& Eggleston 2000). This was the case here for the prey of P. spinifer and Ebalia tuberosa. Predation can also be interrupted to save energy, with hypoxia-induced starvation potentially posing a greater threat than low DO values (Baden et al. 1990). In contrast, more tolerant pelagic or opportunistic predators can exploit moribund or slowly recovering benthos (Karlson et al. 2002, Norkko et al. 2006). The anemone Calliactis parasitica, for example, took advantage of the situation (see also Riedel et al. 2008a) and predated one Ethusa mascarone at severe hypoxia after the crab discarded its protective shell. Discarding camouflage is a sublethal behaviour also observed in the sea urchin Psammechinus microtuberculatus (Riedel et al. 2008b). Holding a shell fragment is apparently energetically costly and may restrict mobility. One shell-less Ethusa mascarone climbed high up an oxygen sensor, perhaps extending its survival time. Nonetheless, E. mascarone discarded its camouflage relatively late $\left(0.23 \mathrm{ml} \mathrm{l}^{-1} \mathrm{DO}\right)$. This indicates a trade-off between predation risk, mobility and obtaining sufficient oxygen.

\section{Mortality and survival}

While crustaceans are among the most sensitive taxa to low DO and to $\mathrm{H}_{2} \mathrm{~S}$ (Theede et al. 1969, Gray et al. 2002, Vaquer-Sunyer \& Duarte 2008), those living in environments with permanently or temporarily low oxygen concentrations, such as thalassinideans, are remarkably tolerant (Atkinson \& Taylor 2005). Mortalities typically occur below $1 \mathrm{ml} \mathrm{l}^{-1} \mathrm{DO}$, and mass mortality below $0.5 \mathrm{ml} \mathrm{l}^{-1}$ (Diaz \& Rosenberg 1995). The mortality thresholds in our study were mainly below $0.5 \mathrm{ml} \mathrm{l}^{-1} \mathrm{DO}$ (overall median: $0.03 \mathrm{ml} \mathrm{l}^{-1} \mathrm{DO}$ ). Mortality was rapid when prolonged severe hypoxia or anoxia occurred. After a median $21.5 \mathrm{~h}$ of hypoxia, almost all crustaceans were dead, indicating a general low tolerance. Many species that can cope with shortterm hypoxia by changing their behaviour or adapting physiologically cannot survive extended or severe events (Hagerman \& Szaniawska 1988, Airriess \& McMahon 1994). Crustaceans may generally lack efficient physiological adaptations (Bernatis et al. 2007), promoting the initial vertical escape reaction. Limited anaerobic capacities may also help explain low survival rates (Hagerman \& Vismann 1995).

The sequence of mortality was the same in all deployments. Thus, from a monitoring standpoint, dead anomurans (Pisidia longimana and Galathea spp.) and majoidean crabs indicate severe hypoxia, whereas dead Ethusa mascarone and Pilumnus spinifer indicate anoxia. Juveniles and smaller individuals tended to die earlier than adults in the same deployment. This confirms the role of size and development stage, whereby juveniles and moulting crabs are more sensitive than adults (Stickle et al. 1989, Eriksson \& Baden 1997), as are smaller individuals of a particular species (e.g. Mundia quadrispina; Burd \& Brinkhurst 1984).

Finally, the course of hypoxia is known to influence mortality and survival times (e.g. polychaetes; Llansó 1991), which we observed here for crustaceans as well. A rapid drop killed the crustaceans at clearly higher DO concentrations and shortened survival times (e.g. Pisidia longimana). This scenario may limit the ability to flee, adapt, or otherwise compensate (McMahon 2001). For all species except Pilumnus spinifer and Ebalia tuberosa, mortality is directly attributable to oxygen depletion because they died before $\mathrm{H}_{2} \mathrm{~S}$ developed. We therefore identify hypoxia as the limiting factor. $\mathrm{H}_{2} \mathrm{~S}$ considerably decreases tolerance to oxygen depletion (Kang et al. 1993), reduces survival times by an average of $30 \%$ (Vaquer-Sunyer \& Duarte 2010), and clearly promoted the mortality of crustaceans still alive at anoxia here. In E. tuberosa, for example, 12 to $21 \mu \mathrm{mol} \mathrm{l} \mathrm{l}^{-1} \mathrm{H}_{2} \mathrm{~S}$ were measured at the time of death. A similar concentration (16.2 $\mathrm{mmol} \mathrm{l}^{-1} \mathrm{H}_{2} \mathrm{~S}$ ) causes paralysis in the brown shrimp Crangon crangon (Vismann 1996).

Ebalia tuberosa and Nepinnotheres pinnotheres survived prolonged hypoxia as well as anoxia. The burying lifestyle of the former involves behavioural and morphological adaptations of the respiratory system, namely increased heart and scaphognathite activity and thus gill ventilation (Schembri 1979), which may provide benefits during hypoxia. Two E. tuberosa survived at least $14 \mathrm{~h}$ of anoxia (deployment ended), and one died after $19 \mathrm{~h}$. Schembri (1979) found similar mortality thresholds (10 to $20 \mathrm{~h}$ ) at anoxia for E. tuberosa in aquarium experiments. Nevertheless, this species tolerates hypoxic/ anoxic conditions and low $\mathrm{H}_{2} \mathrm{~S}$ concentrations (max. $19.2 \mu \mathrm{mol} \mathrm{l}^{-1}$ ) for at least 1 to $2 \mathrm{~d}$.

Anoxia triggered the first visible response (host abandonment) in both Nepinnotheres pinnotheres. This points to high tolerance, but is nevertheless a very unusual behaviour for female individuals (Christensen \& McDermott 1958). Pea crabs, especially species living in bivalves, are well adapted to low oxygen concentrations (Stauber 1945). Here, they also showed high tolerance to $\mathrm{H}_{2} \mathrm{~S}$. In general, marine species with a high tolerance toward oxygen deficiency also cope better with sulphidic conditions (Theede et al. 1969). Based on its late reaction and 
survival, $N$. pinnotheres can be classified as highly tolerant of hypoxia and anoxia and as $\mathrm{H}_{2} \mathrm{~S}$ tolerant for at least 1 to $3 \mathrm{~d}$.

\section{CONCLUSION}

The present study highlights the complexity and interdependence of abiotic and biotic factors as well as inter- and intraspecific interactions in influencing and differentiating low-DO-related responses, survival times, and mortality rates of crustaceans in situ. The distinct behaviours and common patterns demonstrate the benefit of using this sensitive group as an early warning signal to gauge the severity of the low DO events that can lead to dead zones in shallow coastal seas.

Acknowledgements. This research was conducted in the framework of project P17655-B03 (Austrian Science Fund; FWF). We thank P. Steiner and I. Gallmetzer for technical and diving support, P. Dworschak (Natural History Museum Vienna) for help with crustacean identification, and J. Ott and J. Hohenegger for comments and discussion on an earlier version of this manuscript. Special thanks to the director and staff of the Marine Biology Station (MBS) in Piran, Slovenia, for their hospitality and support during our field work.

\section{LITERATURE CITED}

Airriess C, McMahon B (1994) Cardiovascular adaptations enhance tolerance to environmental hypoxia in the crab Cancer magister. J Exp Biol 190:23-41

Aréchiga H, Fernéndez-Quiróz F, de Miguel FF, RodríguezSosa L (1993) The circadian system of crustaceans. Chronobiol Int 10:1-19

Artegiani A, Paschini E, Russo A, Bregant D, Raicich F, Pinardi N (1997) The Adriatic Sea general circulation. Part I: Air-sea interactions and water mass structure. J Phys Oceanogr 27:1492-1514

Atkinson RJA, Taylor AC (2005) Aspects of the physiology, biology and ecology of thalassinidean shrimps in relation to their burrow environment. Oceanogr Mar Biol Annu Rev 43:173-210

Baden SP, Pihl L, Rosenberg R (1990) Effects of oxygen depletion on the ecology, blood physiology and fishery of the Norway lobster Nephrops norvegicus. Mar Ecol Prog Ser 67:141-155

Bernatis JL, Gerstenberger SL, McGaw IJ (2007) Behavioural responses of the Dungeness crab, Cancer magister, during feeding and digestion in hypoxic conditions. Mar Biol 150:941-951

Burd BJ, Brinkhurst RO (1984) The distribution of the galatheid crab Mundia quadrispina (Benedict 1902) in relation to oxygen concentrations in British Columbia fjords. J Exp Mar Biol Ecol 81:1-20

Burnett LE, Stickle WB (2001) Physiological responses to hypoxia. In: Rabalais NN, Turner RE (eds) Coastal hypoxia: consequences for living resources and ecosystems. Coastal and estuarine studies, Vol 58. American Geophysical Union, Washington, DC, p 101-114
Christensen AM, McDermott JJ (1958) Life-history and biology of the oyster crab Pinnotheres ostreum Say. Biol Bull (Woods Hole) 114:146-179

Dade WB, Hogg AJ, Boudreau BP (2001) Physics of flow above the sediment-water interface. In: Boudreau BP, Jørgensen BB (eds) The benthic boundary layer: transport processes and biogeochemistry. Oxford University Press, Oxford

deCoursey PJ (1983) Biological timing. In: Bliss DE (ed) The biology of crustacea, Vol 7. Academic Press, New York, p $107-152$

deFur P, Mangum CP, Reese JE (1990) Respiratory responses of the blue crab Callinectes sapidus to long-term hypoxia. Biol Bull (Woods Hole) 178:46-54

Degobbis D, Fonda-Umani S, Franco P, Malej A, Precali R, Smodlaka N (1995) Changes in the northern Adriatic ecosystem and the hypertrophic appearance of gelatinous aggregates. Sci Total Environ 165:43-58

deGrave S, Turner JR (1997) Activity rhythms of the squat lobsters, Galathea squamifera and G. strigosa (Crustacea: Decapoda: Anomura) in south-west Ireland. J Mar Biol Assoc UK 77:273-276

> Diaz RJ (2001) Overview of hypoxia around the world. J Environ Qual 30:275-281

Diaz RJ, Rosenberg R (1995) Marine benthic hypoxia: a review of its ecological effects and the behavioural responses of benthic macrofauna. Oceanogr Mar Biol Annu Rev 33:245-303

> Diaz RJ, Rosenberg R (2008) Spreading dead zones and consequences for marine ecosystems. Science 321: 926-929

> Eriksson SP, Baden SP (1997) Behaviour and tolerance to hypoxia in juvenile Norway lobster (Nephrops norvegicus) of different ages. Mar Biol 128:49-54

Fedra K, Ölscher E, Scherübel C, Stachowitsch M, Wurzian R (1976) On the ecology of a north Adriatic benthic community: distribution, standing crop and composition of the macrobenthos. Mar Biol 38:129-145

> Gray JS, Wu RSS, Or YY (2002) Effects of hypoxia and organic enrichment on the coastal marine environment. Mar Ecol Prog Ser 238:249-279

Hagerman L, Szaniawska A (1986) Behaviour, tolerance and anaerobic metabolism under hypoxia in the brackishwater shrimp Crangon crangon. Mar Ecol Prog Ser 34: $125-132$

> Hagerman L, Szaniawska A (1988) Respiration, ventilation and circulation under hypoxia in the glacial relict Saduria (Mesidotea) entomon. Mar Ecol Prog Ser 47:55-63

Hagerman L, Uglow RF (1984) The influence of hypoxia on the blood regulation of the brackish water shrimp Palaemonetes varians Leach. J Exp Mar Biol Ecol 76:157-165

> Hagerman L, Vismann B (1995) Anaerobic metabolism in the shrimp Crangon crangon exposed to hypoxia, anoxia and hydrogen sulfide. Mar Biol 123:235-240

Haselmair A (2008) Experimentally induced anoxia in the northern Adriatic Sea: behavioural responses and mortalities of benthic crustaceans. MS thesis, University of Vienna

Herndl GJ, Peduzzi P, Fanuko N (1989) Benthic community metabolism and microbial dynamics in the Gulf of Trieste (northern Adriatic Sea). Mar Ecol Prog Ser 53:169-178

Jeroschewski P, Steuckart C, Kühl M (1996) An amperomeric microsensor for the determination of $\mathrm{H}_{2} \mathrm{~S}$ in aquatic environments. Anal Chem 68:4351-4357

Johansson B (1997) Behavioural response to gradually declining oxygen concentration by Baltic Sea macrobenthic crustaceans. Mar Biol 129:71-78 
Justić D, Rabalais NN, Turner ER, Wiseman JWJ (1993) Seasonal coupling between riverborne nutrients, net productivity and hypoxia. Mar Pollut Bull 26:184-189

Kang J, Matsuda O, Yamamoto T (1993) Effects of low dissolved oxygen and hydrogen sulfide on early developmental stages of blue crab, Portunus trituberculatus in Hiroshima Bay, Japan. J Fac Appl Biol Sci Hiroshima Univ 32:61-70

Karlson K, Rosenberg R, Bonsdorff E (2002) Temporal and spatial large-scale effects of eutrophication and oxygen deficiency on benthic fauna in Scandinavian and Baltic waters: a review. Oceanogr Mar Biol Annu Rev 40:427-489

Knutzen J (1981) Effects of decreased pH on marine organisms. Mar Pollut Bull 12:25-29

Levin LA, Ekau W, Gooday AJ, Jorissen F and others (2009) Effects of natural and human-induced hypoxia on coastal benthos. Biogeosci Discuss 6:3563-3654

Llansó RJ (1991) Tolerance of low dissolved oxygen and hydrogen sulfide by the polychaete Streblospio benedicti (Webster). J Exp Mar Biol Ecol 153:165-178

Lotze HK, Lenihan HS, Bourque BJ, Bradbury RH and others (2006) Depletion, degradation, and recovery potential of estuaries and coastal seas. Science 312:1806-1809

May EB (1973) Extensive oxygen depletion in Mobile Bay, Alabama. Limnol Oceanogr 18:353-366

McMahon BR (2001) Respiratory and circulatory compensation to hypoxia in crustaceans. Respir Physiol 128:349-364

Mistri M (2004) Effects of hypoxia on predator-prey interactions between juvenile Carcinus aestuarii and Musculista senhousia. Mar Ecol Prog Ser 275:211-217

> Norkko A, Rosenberg R, Thrush SF, Whitlatch RB (2006) Scale- and intensity-dependent disturbance determines the magnitude of opportunistic response. J Exp Mar Biol Ecol 330:195-207

Pallas A, García-Calvo B, Corgos A, Bernárdez C, Freire J (2006) Distribution and habitat use patterns of benthic decapod crustaceans in shallow waters: a comparative approach. Mar Ecol Prog Ser 324:173-184

Pihl L, Baden SP, Diaz RJ (1991) Effects of periodic hypoxia on distribution of demersal fish and crustaceans. Mar Biol 108:349-360

Rabalais NN, Turner RE, Scavia D (2002) Beyond science into policy: Gulf of Mexico hypoxia and the Mississippi River. BioScience 52:129-142

Reiffenstein RJ, Hulbert WC, Roth SH (1992) Toxicology of hydrogen sulfide. Annu Rev Pharmacol Toxicol 32: 109-134

Renaud ML (1986) Detecting and avoiding oxygen deficient sea water by brown shrimp, Penaeus aztecus (Ives), and white shrimp Penaeus setiferus (Linnaeus). J Exp Mar Biol Ecol 98:283-292

Riedel B, Stachowitsch M, Zuschin M (2008a) Sea anemones and brittle stars: unexpected predatory interactions during induced in situ oxygen crises. Mar Biol 153: 1075-1085

Riedel B, Zuschin M, Haselmair A, Stachowitsch M (2008b) Oxygen depletion under glass: behavioural responses of benthic macrofauna to induced anoxia in the northern Adriatic. J Exp Mar Biol Ecol 367:17-27

Rosenberg R, Hellman B, Johansson B (1991) Hypoxic tolerance of marine benthic fauna. Mar Ecol Prog Ser 79: $127-131$

Russo A, Maccaferri S, Djakovac T, Precali R and others (2005) Meteorological and oceanographic conditions in the northern Adriatic Sea during the period June 1999-July 2002: influence on the mucilage phenomenon. Sci Total Environ 353:24-38
Sagasti A, Schaffner LC, Duffy JE (2001) Effects of periodic hypoxia on mortality, feeding and predation in an estuarine epifaunal community. J Exp Mar Biol Ecol 258: 257-283

Sala E, Knowlton N (2006) Global marine biodiversity trends. Annu Rev Environ Resour 31:93-122

> Sandberg E (1994) Does short-term oxygen depletion affect predator-prey relationships in zoobenthos? Experiments with the isopod Saduria entomon. Mar Ecol Prog Ser 103:73-80

> Schembri PJ (1979) Oxygen consumption and the respiratory responses to declining oxygen tension in the crab Ebalia tuberosa (Pennant) (Crustacea: Decapoda: Leucosiidae). J Exp Mar Biol Ecol 41:133-142

Stachowitsch M (1979) Movement, activity pattern, and role of a hermit crab population in a sublittoral epifaunal community. J Exp Mar Biol Ecol 39:135-150

Stachowitsch M (1984) Mass mortality in the Gulf of Trieste: the course of community destruction. PSZN I: Mar Ecol 5: 243-264

Stachowitsch M (1991) Anoxia in the northern Adriatic Sea: rapid death, slow recovery. In: Tyson RV, Pearson TH (eds) Modern and ancient continental shelf anoxia. Geological Society, Special Publication, London, p 119-129

Stachowitsch M, Riedel B, Zuschin M, Machan R (2007) Oxygen depletion and benthic mortalities: the first in situ experimental approach to documenting an elusive phenomenon. Limnol Oceanogr Methods 5:344-352

Stauber LA (1945) Pinnotheres ostreum, parasitic on the American oyster, Ostrea (Gryphaea) virginica. Biol Bull (Woods Hole) 88:269-291

Števčić Z (1975) Autecological investigations of the crab Pilumnus spinifer (H. Milne Edwards) in the region Rovinj. Ekologija 10:183-189

Stickle WB, Kapper MA, Liu LL, Gnaiger E, Wang SY (1989) Metabolic adaptations of several species of crustaceans and molluscs to hypoxia: tolerance and microcalorimetric studies. Biol Bull (Woods Hole) 177:303-312

Supić N, Orliç M, Degobbis D, Dakovac T, Krajcar V, Precali $\mathrm{R}$ (2002) Occurrence of the Istrian Coastal Countercurrent in 2000, a year with a mucilage event. Geofizika 18-19: 45-57

Taylor DL, Eggleston DB (2000) Effects of hypoxia on an estuarine predator-prey interaction: foraging behavior and mutual interference in the blue crab Callinectes sapidus and the infaunal clam prey Mya arenaria. Mar Ecol Prog Ser 196:221-237

Theede H, Ponat A, Hiroki K, Schlieper C (1969) Studies on the resistance of marine bottom invertebrates to oxygen-deficiency and hydrogen sulphide. Mar Biol 2: 325-337

> Vaquer-Sunyer R, Duarte CM (2008) Thresholds of hypoxia for marine biodiversity. Proc Natl Acad Sci USA 105: 15452-15457

> Vaquer-Sunyer R, Duarte CM (2010) Sulfide exposure accelerates hypoxia-driven mortality. Limnol Oceanogr 55: 1075-1082

Vismann B (1991) Sulfide tolerance: physiological mechanisms and ecological implications. Ophelia 34:1-27

Vismann B (1996) Sulfide species and total sulfide toxicity in the shrimp Crangon crangon. J Exp Mar Biol Ecol 204: 141-154

Vismann B, Hagerman L (1996) Recovery from hypoxia with and without sulfide in Saduria entomon: oxygen debt, reduced sulfur and anaerobic metabolites. Mar Ecol Prog Ser 143:131-139

Wannamaker CM, Rice JA (2000) Effects of hypoxia on move- 
ments and behavior of selected estuarine organisms from the southeastern United States. J Exp Mar Biol Ecol 249: 145-163

Wu RSS (2002) Hypoxia: from molecular responses to ecosystem responses. Mar Pollut Bull 45:35-45

Wurzian RS (1977) Predator-prey interaction between the crab Pilumnus hirtellus (Leach) and the brittle star Ophiothrix quinquemaculata (D. Chiaje) on a mutual sponge substrate. In: Keegan BF, O'Ceidigh P, Boaden PJS (eds) Biology of benthic organisms, 11th EMBS Galway. Pergamon Press, Oxford, p 613-620

Wurzian RS (1982) Die Funktion der Räuber der Makro-Epi-

Editorial responsibility: Inna Sokolova,

Charlotte, North Carolina, USA fauna in einer sublitoralen Benthos Gemeinschaft im Golf von Trieste. $\mathrm{PhD}$ thesis, University of Vienna

Zavatarelli M, Raicich F, Bregant D, Russo A, Artegiani A (1998) Climatological biogeochemical characteristics of the Adriatic Sea. J Mar Syst 18:227-263

Zuschin M, Stachowitsch M (2009) Epifauna-dominated benthic shelf assemblages: lessons from the modern Adriatic Sea. Palaios 24:211-221

Zuschin M, Pervesler P, Stachowitsch M, Kollmann H (1999) Structural features and taphonomic pathways of a highbiomass epifauna in the northern Gulf of Trieste, Adriatic Sea. Lethaia 32:299-317

Submitted: December 7, 2009; Accepted: May 10, 2010 Proofs received from author(s): August 20, 2010 